\title{
About domestic lexical features in translation "Zafarnama" expressing the household
}

\author{
Azamat Primov ${ }^{1}$, Sumbul Muhammedova ${ }^{2}$ \\ ${ }^{1}$ Candidate of Philology, Associate Professor, Department of Uzbek Linguistics, \\ Urgench State University, Uzbekistan. \\ ${ }^{2}$ Student of the Faculty of Philology, Urgench State University, Uzbekistan
}

\begin{abstract}
This paper investigates major points of the domestic lexical points in translation "Zafarnama" expressing the household. on this way, research has analysed features both theoretically and methodologically. that mentioned on different points to do research on lexical translation as a conclusion.
\end{abstract}

Keywords: domestic, lexical, features, translation, "Zafarnama», household.

\section{INTRODUCTION}

It is known that few prosaic sources have survived until now, incorporating features of an old 16thcentury Old Uzbek language.

One of the unique examples in which the state of the old Uzbek literary language of the beginning of the 16th century was fully imprinted is the translation of the work of Sharafuddin Ali Yazdi "Zafarnama" into the old Uzbek language. This work was created in Farsi and completed in the year 828 AH (1424-1425 BC). The Uzbek translation of this work, which was carried out by Muhammad Ali ibn Darves Ali al-Bukhari in 1519 , that is, almost a hundred years after writing this unique monument of writing, has a very significant significance. $(1,2)$ The above translation reflects and changes in the lexical structure of the old Uzbek language of the XVI century. In this regard, this source is important for the study of linguistic features of the era. Translated "Zafarnama" special place is occupied by household vocabulary, which is directly related to the kitchen, living room and bedroom. Next, we use the example of individual words to consider the originality of everyday vocabulary.

The word "ayak" in the ancient Türkic language was used in the meaning of "cup", "bowl", in the "Dictionary of Turkic adverbs" - "vessel", "bowl", "drinking bowl". In the language of "Zafarnama", the word is used in the meaning of "cup" and "bowl": Shaoдazodalar navbat beat aуғғ tutub icha boshladilar. The princes in turn began to lift and empty the glasses (1.299a); Beklar etiyut qildilar, bir botmon uluf tosh bilan oltmish ayq balmoq bildi va muharrarr qildilar: cherik kishishi Kara coon bilof beat qanoat Kilnsunlar v kub kishi bor Erdikim ... (1.119b) The Becks recalled those times when one big stone was exchanged for sixty bowls of soup, and noted that each warrior should be satisfied with one serving daily, like all the others ... (1.119b). In the modern Uzbek language, this word is used in the structure of the Yiddish-Oek (pair) tableware.

\section{MAIN PART}

In the language of the work, the word tobacco is found in the meaning of "gold or wooden dishes for food storage "Let's eat using this new golden dish". Rich people mentioned, "Oltun Tabak does not Press Turur, yachoch Tabatetar". The Becky replied, "Golden dishes are not needed, you can get by with wooden" (1.75a)

The word "Piala" was transferred to the Turkic languages from Iranian and means, basically, a vessel for tea drinking. Here we are talking about drinking bowls made of gold and crystal. Wa ofobdek sojilar oltun pyelarni to'ldurub tutaboslaladilar. And the butlers began to fill and serve gold bowls. (1.299a)

The word "chick" (knife) is of Turkic origin and is formed on the basis of bi in the meaning of "blade", "face". On the basis of bi, a verb with an affix-h bichmoq was formed from a noun, then with the addition of a word-formation affix -ac the word "scramble" was formed. (3.30) Since the sounds of b and $\mathrm{n}$ are paired according to voiced-deafness, the said word was subsequently modified and began to sound in the shape of a spike. This word is used both as a kitchen utensil and as a military tool as a synonym for the word hanjaj 
(dagger). Va ul muxassil azobidine Yziga pichou Urdi. And not bearing the insult, deal a blow with a dagger. (1.253b)

The word Hum defines clay vessels of various sizes for storing liquids, grains and other things; in the work it is used to store canned products: Alar Chumchulardin Tutub, Ace Urub, Ko'zalarda Humlarda Solur Erdilar. They caught sparrows, mothballed them and placed them in various jugs. (1.119b) Sh. Usmanova notes that the etymology of the word "Gumgon" must be searched for in the element Qum // Kum, recalling that the word "Gumra" from the Kyrgyz language also has the meaning of a clay jug. The word "Kumgon" in the Altai languages, meaning "hole, deepening, depth", as well as the word "godfather" from Uzbek dialects (dugout, hunting hut) appeared from this basis. In the dialects of Khorezm to this day, the doghouse for a dog is called Kuma, the place of burning bricks and making clay products is called Humbuz (Humpaz).

\section{DISCUSSION}

The word "ko'za" (a large jug) defined, as usual, a vessel with a voluminous gut and narrow neck, intended for storing liquids, which, like the word "hum", was probably used to determine the meaning of "hole, groove". The expressions "buloqning ko'zi", "derazaning ko'zi" used in the Uzbek language, in which the metaphorical use of the word "ko'z" (eye) is observed, also confirms this hypothesis. A similar phenomenon is observed in the revolutions of "Summing-up Ozi", "Shocking-up Ozi" (announcing).

In the language of "Zafarnama", the word "oftoba" (narrow-necked jug) is not used, however, judging by the use of the word "oftobachi" by the translator in the meaning of "position of the person who supplied the washstand for guests during the khanate period", the word "oftoba ": Va Odil oftobachi ul" Arming boshes uzra qalqonini tutub turdi ... And the devotee held a shield above his master's head. (1.140b) The word "oftoba" is a component in Farsi, consisting of two parts and formed on the basis of the connection of the verb aft in the meaning of "fall" and the word on in the meaning of "water", resulting in the name of the vessel in the meaning of "pour water".

The word "Sanoch" (waterskin) in various sources is defined as "a special leather container for storing various liquids, as well as grain and flour and other food (leather bag, bag)". Cherikka fever ekkursunlarkim, kishi boshika ikki sanoch o'zi bilan olib turuaykim, Tongla suvdin o'tarda kerak bo'lfai turur ". Each warrior should have two waterskins with him, which will help him overcome all obstacles. (1.146a)

. Having unrolled a tablecloth, they achieved satisfaction of their desires (1.184b) The word "dasturhon" in Tajik language sounds like "dastorhon". (7.350) E.Vahidov notes that the word "dasturkhon" is formed on the basis of two words "dastor" and "hvana".

In the vocabulary of "Zafarnama" there are a lot of words that define various household utensils related to the living room and bedroom. Kigiz (koshma) is made of wool, serving as a flooring, and in this sense is synonymous with the word "matt". This word, which in the most ancient monuments has the form "kidiz", in the "Dictionary of Turkic adverbs" has the sound "kiyiz" in one place, and in the other - "kuvuz", in the language of the studied work it is used in the form "kiyiz". In the work, the word namad is used as a synonym for this word. It is a borrowing from the Farsi language, here it is used in the form indicated: tokim yana bir baland toqqa ettilar. In the afternoon, the ice began to get under way, and the snowstorm was thrown onto the snow, carpets and carpets, so that the horses could move to the top of the mountain." (1.188a)

At present, this word used in the dialects of Khorezm in the form of "kiyiz" in the literary language sounds in the form of "kigiz"; the word "namad" in literary language and dialects is used in the form "namat".

In the language of the work, the words zilzha / / zilizha were used once, which convey the meaning of "cheap carpet" and "palace". This word in the Tajik language has the form "Zilu". The word "holiday" is not found in dictionaries. Shozodalar va baklar khodirlarini va Izilzha takya, namdlarini balchik solib o'ttilar. The princes and the Beks overcame the mud through nightmares, carpets and pillows. (1.155a)

\section{RESULT}

The word "gilam" (carpet) defines the name of an object that is made of wool and silk and is laid on the floor in a house or hung on a wall. This word is a transformation in the Uzbek language of the Persian word "Kelim", meaning "palace", "smooth carpet". In Tajik, it is used in the form of "gil".

The word "carcass" (mattress, mattress) is a bedroom affiliation that is made by filling a cover of this kind of raw material, such as cotton, wool, silk, and down, in the work it is also used in a figurative sense:

Тушак маразики душманинг еридур,

Бадхохларингга ул дамо-дам бўлвай.

Тюфяк является уделом врагов, страдающих язвой, 


\section{Пусть они никогда не поднимутся с него.}

(1.118a)

At present, this word used in the dialects of Khorezm in the form of "kiyiz" in the literary language sounds in the form of "kigiz"; the word "namad" in literary language and dialects is used in the form "namat".

In the language of the work, the words zilzila was used once, which convey the meaning of "cheap carpet" and "palace". This word in the Tajik language has the form "Zilu". The word "holiday" is not found in dictionaries. Quences and Beks also mentioned these words in their actions. The princes and the Beks overcame the mud through nightmares, carpets and pillows. (1.155a)

\section{CONCLUSION}

In General, if some of the words related to household vocabulary from "Zafarnama" in modern Uzbek literary language and dialects are used in similar form and meaning, others have become obsolete, have purchased other seven, in contrast to their values in the language of the work

\section{REFERENCES}

1. A copy of the translation "Zafar-name" by Muhammad Ali, stored at number 3268 in the library of Nuri Usmoniy in the city of Istanbul.

2. Sharafuddin Ali Yazdi. Zafar name (The authors of the preface, amendments, comments, notes and preparation for publication: Ashraf Ahmad, Khaidarbek Bobobekov) - Tashkent: Shark, 1997. -384 p.

3. Research on the vocabulary of the Turkic languages of Central Asia and Kazakhstan. - Tashkent: Fan, 1990. - p. 95.

4. Mahmud of Kashgar. Divani lugatit Turk. (Dictionary of Turkic adverbs): In 3 volumes. Tashkent: Publishing House of the Academy of Sciences of the UzSSR, 1960-1963. - T.1. 1960. 499 p., V.2. 1961. - 427 p., V.3. 1963. 466 p.

5. Vakhidov E. Word beauty. - Tashkent, 2017.

6. Miller Persian-Russian dictionary. - M., 1960. - p. 99.

7. Farxangi zaboni points. T.1. $\neg-$ M .: "Soviet Encyclopedia", 1969. -P. 350

8. sThe explanatory dictionary of the language of works of Alisher Navoi: in 4 volumes. -Tashkent: Fan, 1983-1985. - T.1. 1983. - 656 p., T. 2. 1983. - 643 p., T. 3. 1984. - 624 p., T. 4. 1985. - 636 p. 